\title{
Dwarf Copper-Gold Porphyry Deposits of the Buchim-Damjan- Borov Dol Ore District, Republic of Macedonia (FYROM)
}

\author{
T. Serafimovski ${ }^{a}$, V. Stefanova ${ }^{a}$, and A. V. Volkov ${ }^{b}$ \\ 'Faculty of Mining and Geology, Goce Del'rev University, \\ Stip, Republic of Macedonia (FYROM) \\ ${ }^{b}$ Institute of Geology of Ore Deposits, Petrography, Mineralogy, and Geochemistry, Russian Academy of Sciences, \\ Staromonetnyi per. 35, Moscow, 119017 Russia
}

Received December 12, 2009

\begin{abstract}
The metallogenic aspects, tectonic setting, magmatism, structure, and composition of Au- and Ag-bearing porphyry copper deposits in the Buchim-Damjan-Borov Dol ore district and their genetic features are considered and compared with earlier published data. Special attention is paid to supergene gold in heavy concentrate halos of the Borov Dol deposit. The total $\mathrm{Cu}$ reserves of the deposits discussed in this paper do not exceed $150 \mathrm{kt}$. The Buchim deposit likely is the world's smallest deposit of this type currently involved in mining. A comprehensive study of these dwarf porphyry copper deposits is undertaken to answer questions on the conditions of their formation. How do they differ from formation conditions of giant deposits?
\end{abstract}

DOI: $10.1134 / \mathrm{S} 1075701510030013$

\section{INTRODUCTION}

The localization and formation conditions of porphyry copper giants have been the subjects of numerous investigations. The main question posed in most publications is how did they form (Cook et al., 2005; Volkov et al., 2006). The total $\mathrm{Cu}$ reserves of the porphyry copper deposits in the Buchim-DamjanBorov Dol ore district discussed in this paper do not exceed $150 \mathrm{kt}$. The Buchim deposit is likely the world's smallest deposit of this type currently involved in mining. The successful mining of this deposit for many years refutes the popular opinion that the porphyry copper deposits profitable for mining must contain no less than $2.5 \mathrm{Mt}$ of copper and the $\mathrm{Cu}$ grade in ore should be higher than $0.5 \%$. Therefore, the comprehensive study of the dwarf deposits of Macedonia is as important to answer the question on their formation conditions as that of the giants in the Pacific ore belt. What is a difference of their formation conditions from those of giant deposits?

The Buchim-Damjan-Borov Dol ore district occupies approximately $150 \mathrm{~km}^{2}$ in the southern part of the Republic of Macedonia (Fig. 1). The district is distinguished by widespread Tertiary volcanism accompanied by $\mathrm{Fe}, \mathrm{Cu}, \mathrm{Au}, \mathrm{Pb}$ and $\mathrm{Zn}$ ore mineralization. This ore district had a long exploration history (Petcovic, 1968; Jankovic et al., 1980; Serafimovski

\footnotetext{
Corresponding author: A.V. Volkov. E-mail: (ma2105@mail.ru
}

et al., 1993, 1995, 1996; Cifliganec, 1993; Tudzarov, 1993; Cifliganec et al., 1994; Karamata et al., 1992; Stojanov and Serafimovski, 1990; Stefanova, 2005; Stefanova et al., 2006).

The porphyry copper deposits of this district belong to the Lece-Chalkidiki metallogenic zone localized between the Serbo-Macedonian Massif and the Vardar Zone (Fig. 1) and are genetically related to the Tertiary subvolcanic calc-alkaline stocks: the Buchim, Tular, and Borov Dol in Macedonia; the Vathi, Gerakaria, and Pondokeraséa in Greece, etc. (Table 1). Only the Buchim deposit is currently in operation.

The Buchim deposit located in the northeast of ore district (Fig. 2) has been known since ancient times, but was explored in detail only in the 1970s. Its ore reserves are $120 \mathrm{Mt}$ of ore with an average grade of $0.34 \% \mathrm{Cu}$ and $0.35 \mathrm{~g} / \mathrm{t} \mathrm{Au}$. The deposit has been mined since 1979 . To date, about $80 \mathrm{Mt}$ of ore have been mined out. The annual capability of the mine is $4 \mathrm{Mt}$ of ore. At present, ore with $0.21 \% \mathrm{Cu}, 0.2 \mathrm{~g} / \mathrm{t} \mathrm{Au}$, and $0.8 \mathrm{~g} / \mathrm{t} \mathrm{Ag}$ is being mined. Thirty-two kilotons of concentrate containing $18-21 \% \mathrm{Cu}$ and $18 \mathrm{~g} / \mathrm{t} \mathrm{Au} \mathrm{Au}$ recovery is $50 \%$ ) has been produced. The concentrate is delivered by trucks to smelters at Bor in Serbia and Pirdop in Bulgaria. Since 2005, the Buchim Mine has been owned by the Romtrade Company, an affiliate of the Ural Mining and Metallurgical Company.

The Borov Dol deposit situated in the southwestern part of the district (Fig. 2) is a depot source of ore for 


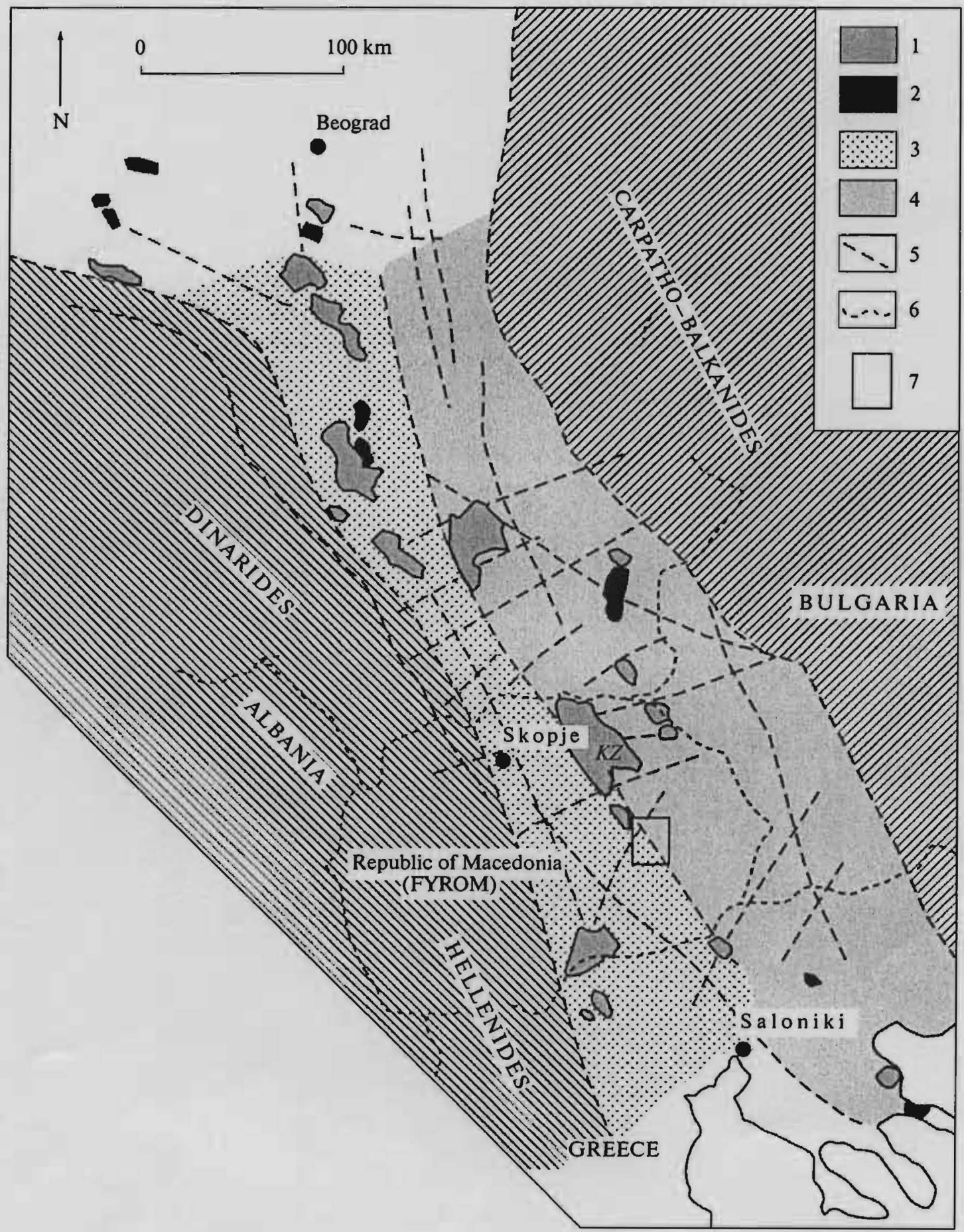

Fig. 1. Geological setting of the Republic of Macedonia in the Balkan region. (1) Tertiary volcanic rocks, (2) Tertiary intrusive rocks, (3) Vardar Zone, (4) Serbo-Macedonian Zone, (5) faults and lineaments, (6) state border, (7) Buchim-Damjan-Borov Dol ore district. 
Table 1. Porphyry copper deposits and occurrences of the Republic of Macedonia (FYROM) and Greece

\begin{tabular}{|c|c|c|c|c|c|}
\hline Deposit & Host rock & Age, Ma & $\begin{array}{c}\text { Horizontal } \\
\text { projection, } \mathrm{km}^{2}\end{array}$ & Vertical range, $\mathrm{m}$ & Ore grade \\
\hline Kiseljak & Andesite & $12-23$ & 0.24 & $300-500$ & $\begin{array}{l}0.3 \% \mathrm{Cu} \\
0.3 \mathrm{~g} / \mathrm{t} \mathrm{Au} \\
1.0 \mathrm{~g} / \mathrm{t} \mathrm{Ag} \\
23 \mathrm{~g} / \mathrm{t} \mathrm{Mo} \\
4-10 \% \text { pyrite }\end{array}$ \\
\hline Buchim & Gneiss and andesite & $25-28$ & 0.25 & 250 & $\begin{array}{l}0.3 \% \mathrm{Cu} \\
0.5 \mathrm{~g} / \mathrm{t} \mathrm{Au} \\
1.1 \mathrm{~g} / \mathrm{t} \mathrm{Ag} \\
13 \mathrm{~g} / \mathrm{t} \mathrm{Mo} \\
1-4 \% \text { pyrite } \\
\text { Traces: } \mathrm{Pd}, \mathrm{Se}, \mathrm{Te}\end{array}$ \\
\hline Borov Dol & Andesite & $24-28$ & 0.15 & 300 & $\begin{array}{l}0.3 \% \mathrm{Cu} \\
0.28 \mathrm{~g} / \mathrm{t} \mathrm{Au} \\
1.50 \mathrm{~g} / \mathrm{t} \mathrm{Ag} \\
24 \mathrm{~g} / \mathrm{t} \mathrm{Mo} \\
2 \% \text { pyrite }\end{array}$ \\
\hline Vathi & Rhyodacite & 30 & 0.1 & 500 & $\begin{array}{l}0.3 \% \mathrm{Cu} \\
0.15 \mathrm{~g} / \mathrm{t} \mathrm{Au} \\
0.35 \mathrm{~g} / \mathrm{t} \mathrm{Ag} \\
20 \mathrm{~g} / \mathrm{t} \mathrm{Mo}\end{array}$ \\
\hline Pondokeraséa & $\begin{array}{l}\text { Rhyodacite and } \\
\text { granosyenite }\end{array}$ & 32 & 0.12 & 500 & $\begin{array}{l}0.3 \% \mathrm{Cu} \\
0.3 \mathrm{~g} / \mathrm{t} \mathrm{Au} \\
0.35 \mathrm{~g} / \mathrm{t} \mathrm{Ag} \\
20 \mathrm{~g} / \mathrm{t} \mathrm{Mo}\end{array}$ \\
\hline Scouries & $\begin{array}{l}\text { Granodiorite por- } \\
\text { phyry }\end{array}$ & 29.6 & 0.02 & 700 & $\begin{array}{l}0.5 \% \mathrm{Cu} \\
0.7 \mathrm{~g} / \mathrm{t} \mathrm{Au} \\
2.5 \mathrm{~g} / \mathrm{t} \mathrm{Ag} \\
\text { Traces: Pd,Te,Pt }\end{array}$ \\
\hline Kadica & $\begin{array}{l}\text { Quartz latite and } \\
\text { slate }\end{array}$ & 27.5 & 0.12 & 300 & $\begin{array}{l}0.2 \% \mathrm{Cu} \\
0.2 \mathrm{~g} / \mathrm{t} \mathrm{Au} \\
0.35 \mathrm{~g} / \mathrm{t} \mathrm{Ag} \\
20 \mathrm{~g} / \mathrm{t} \mathrm{Mo}\end{array}$ \\
\hline Ilovica & $\begin{array}{l}\text { Quartz latite and bi- } \\
\text { otite granite }\end{array}$ & $?$ & 1.0 & 300 & $\begin{array}{l}0.5 \% \mathrm{Cu} \\
0.3-1.0 \mathrm{~g} / \mathrm{t} \mathrm{Au} \\
0.5 \mathrm{~g} / \mathrm{t} \mathrm{Ag} \\
50 \mathrm{~g} / \mathrm{t} \mathrm{Mo}\end{array}$ \\
\hline
\end{tabular}

the Buchim mill. The deposit had been known since 1930 , when the first boreholes penetrated ore containing $0.2-0.7 \% \mathrm{Cu}$. Exploration was carried out in 1973-1977. The reserves are estimated at $40 \mathrm{Mt}$ of ore containing $0.3 \% \mathrm{Cu}$ and $0.28 \mathrm{~g} / \mathrm{t} \mathrm{Au}$.

\section{RESEARCH METHODS}

In recent years, the Buchim-Damjan-Borov Dol ore district was comprehensively studied by a Russian-Macedonian scientific team under a joint research program. The volcanic rocks of this district were investigated using modern analytical techniques.
A microprobe analysis of minerals was carried out at the European Control AD Laboratory for X-ray Spectroscopy using the standards of JEOL Company and a microprobe operating at an acceleration voltage of $20 \mathrm{kV}$ and current intensity of $2 \times 10^{-9} \mathrm{~A}$. Chemical analysis of rocks was performed at the Faculty of Geology and Geography, University of Sofia, Bulgaria. Cr, $\mathrm{Ni}, \mathrm{Co}, \mathrm{Li}, \mathrm{Rb}, \mathrm{Sr}, \mathrm{Zn}, \mathrm{Cu}$, and $\mathrm{Pb}$ were determined on a PerkinElmer atomic absorption spectrometer; other trace elements were determined by XRF at the University of Lausanne, Switzerland.

Special attention was focused on the study of exogenic gold from heavy concentrate halos of the Borov 


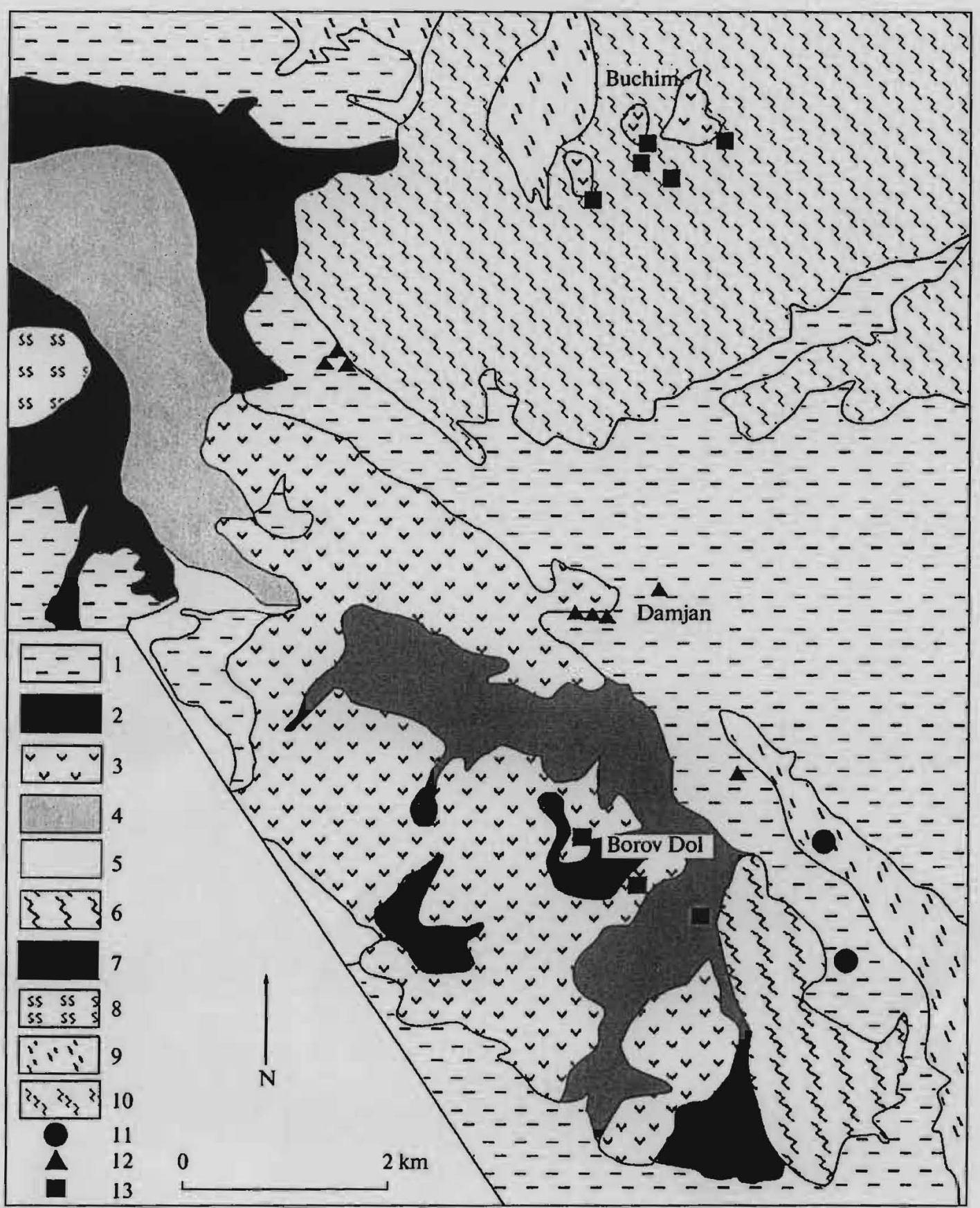

Fig. 2. Geological map of the Buchim-Damjan-Borov Dol ore district. (1) Paleogene, Neogene, and Quaternary sedimentary rocks; (2) pyroclastic rocks; (3) andesite and latite; (4) Quaternary flysch; (5) carbonate rocks; (6) carbonate slate; (7) granite; (8) serpentinite; (9) muscovite schist, (10) gneiss; (11) $\mathrm{Pb}-\mathrm{Zn}$ vein mineralization; (12) iron skarn mineralization; (13) $\mathrm{Cu}-\mathrm{Au}$ porphyry mineralization.

Dol deposit. It is known that the mineralogical study of gold in disseminated ore at porphyry copper deposits meets with difficulties caused by its micron-sized particles and low grades (lower than $1 \mathrm{~g} / \mathrm{t}$ ). Therefore, an original technique has been developed and applied to our objects. The morphology and chemistry of gold particles were examined at the University of Sofia, Bulgaria, on a TN-2000 microprobe (JEOL Company 
standards were used), a JEOL LMS 35CF, and a JEOL JSM-5510 SEM.

\section{TECTONIC AND METALLOGENIC OVERVIEW}

The metallogeny of the southern Balkan Peninsula is determined by the geodynamic evolution of the Tethys-Eurasian metallogenic belt (TEMB), which was outlined by S. Jankovic in 1993, and ancient crystalline massifs. The TEMB formed during post-Mesozoic time on the place of the Jurassic Tethys paleoocean situated between the southern continental margin of Eurasia, on one side, and African-Arabian and Indian plate, on the other side. The belt extends from the western Mediterranean along the Alps and southeastern Europe via the Lesser Caucasus, Hindu Kush, and Tibetan Plateau to Burma and northwestern Indonesia, where it joins the western segment of the Pacific metallogenic belt. The southern Balkan Peninsula, including the Republic of Macedonia, is a sector of the central TEMB (Fig. 1).

The formation of ore deposits was related here to certain chronological stages and geodynamic settings:

(1) Late Permian-Early Triassic intracontinental rifting along the northern boundary of Gondwana and/or its already detached fragments;

(2) Jurassic intracontinental rifting marked by ophiolitic complex;

(3) suprasubduction magmatism; and

(4) postcollision (orogenic) continental setting and related formation of various base- and noble-metal deposits ( $\mathrm{Pb}-\mathrm{Zn}-\mathrm{Ag}, \mathrm{Cu}-\mathrm{Au}, \mathrm{Au}-\mathrm{As}-\mathrm{Sb}-\mathrm{Tl}, \mathrm{Au}-$ $\mathrm{Ag}$ ).

The Jurassic ophiolite belt extends for hundreds of kilometers within Macedonia and for a few thousand kilometers on a global scale via Greece, Turkey, the Caucasus, and Iran to the Himalayas. In Macedonia, the ophiolite complex occurs in the Vardar Zone (VZ) and the adjacent Serbo-Macedonian Massif (SMM) (Karamata and Lovric, 1978). The VZ extends in the NW-SE direction between the SMM and Pelagonian Massif (Fig. 1). Ophiolites of the VZ comprise the Jurassic gabbro-peridotite complex and doleriteslate complex, which are overlain by the Cretaceous flysch. The SMM is located between the Carpathian Mountains and Balkanides in the east and the VZ in the west. Peridotite dikes occur in the SMM along its contact with the VZ.

The collision of the African and Eurasian plates was accompanied by closure of the ocean and subduction of the oceanic crust beneath the SMM. Arches, domes, and grabens developed during this process. Deep faults that formed at the time at the active continental margins have important metallogenic implications.

The above-listed regional tectonic units extending parallel to the VZ control regional metallogenic zones, ore districts, and ore fields (Fig. 1).
Collision, postcollision processes, and Tertiary magmatism were crucial for localization of base-metal ore mineralization.

Cenozoic reactivation embraced largely the eastern part of the Macedonian Arch and was expressed in the development of the NW-trending faults oriented obliquely to the $\mathrm{VZ}$ and the transverse NE-trending faults at the final stage (Tomson et al., 1998; Volkov et al., 2006).

The rocks of the Tertiary volcanic-plutonic complex and related base-metal mineralization occur in four tectonic and metallogenic zones (Fig. 1):

(1) the magmatic zone at the mobile northern, northeastern, and eastern margins of the Dinarides;

(2) the magmatic zone in the severely tectonized central part of the VZ;

(3) the Lece-Chalkidiki metallogenic zone at the contact between SMM and VZ (Zletovo, Plavica, Buchim, Borov Dol, Damjan, Borovich deposits);

(4) the Besna Kobila-Ochagovo metallogenic zone (Sasa, Toranica, Kadica, Ilovica deposits).

The Precambrian metamorphic complex is the oldest in the SMM (Fig. 2). The complex is composed of biotite, muscovite, two-mica, and other gneisses, amphibolites, muscovite schists, and other metamorphic rocks. Gneisses are widespread and favorable for localization of ore.

Paleozoic rocks comprise chlorite-amphibole schists, slate-carbonate group, metagabbro, and dolerite, which are less favorable for the localization of porphyry ore than Precambrian rocks.

The Mesozoides combine Jurassic ultramafic and granitic rocks. Serpentinized peridotites and pyroxenites are locally overlapped by volcanic flows and Quaternary sediments. Granite, granodiorite, and quartz monzonite are accompanied by low-grade chalcopyrite mineralization.

Paleogene sedimentary rocks (conglomerate, tuffaceous flysch, limestone) are cut through by Neogene subvolcanic bodies. These rocks, especially marlstone and shale, are favorable hosts for porphyry and skarn mineralization; they serve as screens for ore-bearing fluids and protoliths for metasomatic alteration.

Neogene conglomerate, gravelstone, sandstone, limestone, and other sedimentary rocks are overlapped by Quaternary clayey and sandy sediments (fans, hillside, and alluvial facies).

The boundary between the VZ and the SMM extends in the central part of the district (Fig. 2). Other important ore-localizing structural elements are volcanic calderas, domes, and dikes. Three variously oriented fault systems are recognized.

The first, NW-trending fault system coincides in the strike with major tectonic units. The second and third systems extend in the northeastern and meridional directions, respectively. The third system has important implications for the development of Ter- 


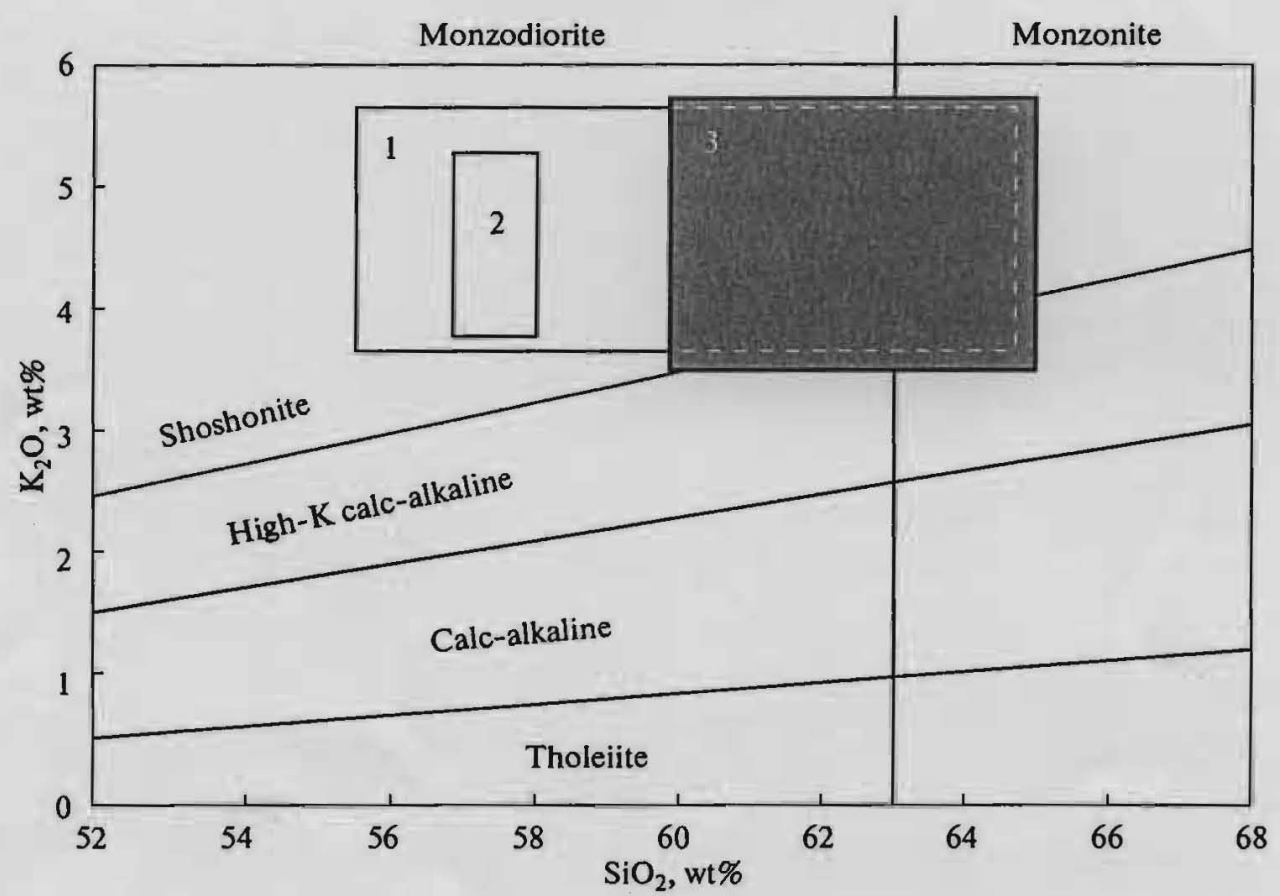

Fig. 3. Chemical compositions of intrusive rocks of (1) active continental margins (Miller and Groves, 2000), (2) Cadia ore district, Australia (Blevin, 2002), and (3) Buchim-Damjan-Borov Dol ore district plotted on the $\mathrm{K}_{2} \mathrm{O}-\mathrm{SiO}_{2}$ classification diagram (Peccerillo and Taylor, 1976).

tiary magmatism and related iron skarn and porphyry copper mineralization. This system controls numerous volcanic domes and necks, which are localized at intersections of near-meridional and northeastern faults.

Volcanic activity progressed beginning from the late Oligocene, and ore mineralization formed in the Miocene. Andesites in the Damjan and Borov Dol volcanic fields formed 28.0-26.5 Ma. Andesitic stocks of the Buchim ore field are dated at 27.0-24.5 Ma. The Buchim porphyry copper deposit is close in age to the andesitic neck (Cifliganec, 1993).

The Bucim-Damjan-Borov Dol ore district with porphyry copper and iron skarn mineralization ocuppies the southwestern part of the Lece-Chalkidiki metallogenic zone. The ore mineralization is concentrated in the Buchim, Damjan, and Borov Dol ore fields (Fig. 2).

The Buchim ore field is localized in the northern part of the ore district within the SMM and is characterized by (1) NW- and NE-trending low-order faults; (2) prevalence of latite and trachylatite as products of Tertiary volcanism, dikes, and minor intrusions; and (3) porphyry copper mineralization. No volcanic domes or calderas expressed in landforms are known. Only small ring structures a few hundreds of meters to $1.5 \mathrm{~km}$ in diameter accompanied emplacement of subvolcanic stocks. The outer parts of such structural forms are composed of gneiss, whereas the inner parts are composed of latitic stocks. Similar structural forms are widespread elsewhere in this ore district.

In addition to the Buchim deposit, numerous porphyry copper occurrences are known in the north of the district (Vranjak, Orljak, Crn-Vrv-Kalapetrivci, Kosevo, Kosevska Reaka, etc.).

The Borov Dol ore field is localized at the margin of a volcanic caldera in the southern part of the ore district within the VZ. The caldera, $5 \mathrm{~km}$ in diameter, is clearly expressed in topography and complicated by several volcanic domes and depressions $1.0-1.5 \mathrm{~km}$ in diameter; one these depressions hosts the Borov Dol deposit. The NW-trending faults control the Neogene latite and quartz latite dikes, necks, and extrusions. The Borov Dol deposit is related to this volcanic-plutonic complex. The ore-bearing volcanic rocks are metasomatically altered.

The volcanic rocks belong to the high-K shoshonitic series and correspond to monzodiorite and monzonite in $\mathrm{K}_{2} \mathrm{O}-\mathrm{SiO}_{2}$ relationships (Fig. 3). These are andesite, latite, trachyte, and rhyolite, including transitional varieties (Fig. 4). It should be noted that the rocks of shoshonitic series are typical of districts with porphyry copper mineralization at continental margins, e.g., Bajo Alumbrera, Gunumba, Bingham, Ok-Tedi, Grasberg, Cadia, etc. (Miller and Groves, 2000; Blevin, 2002). 


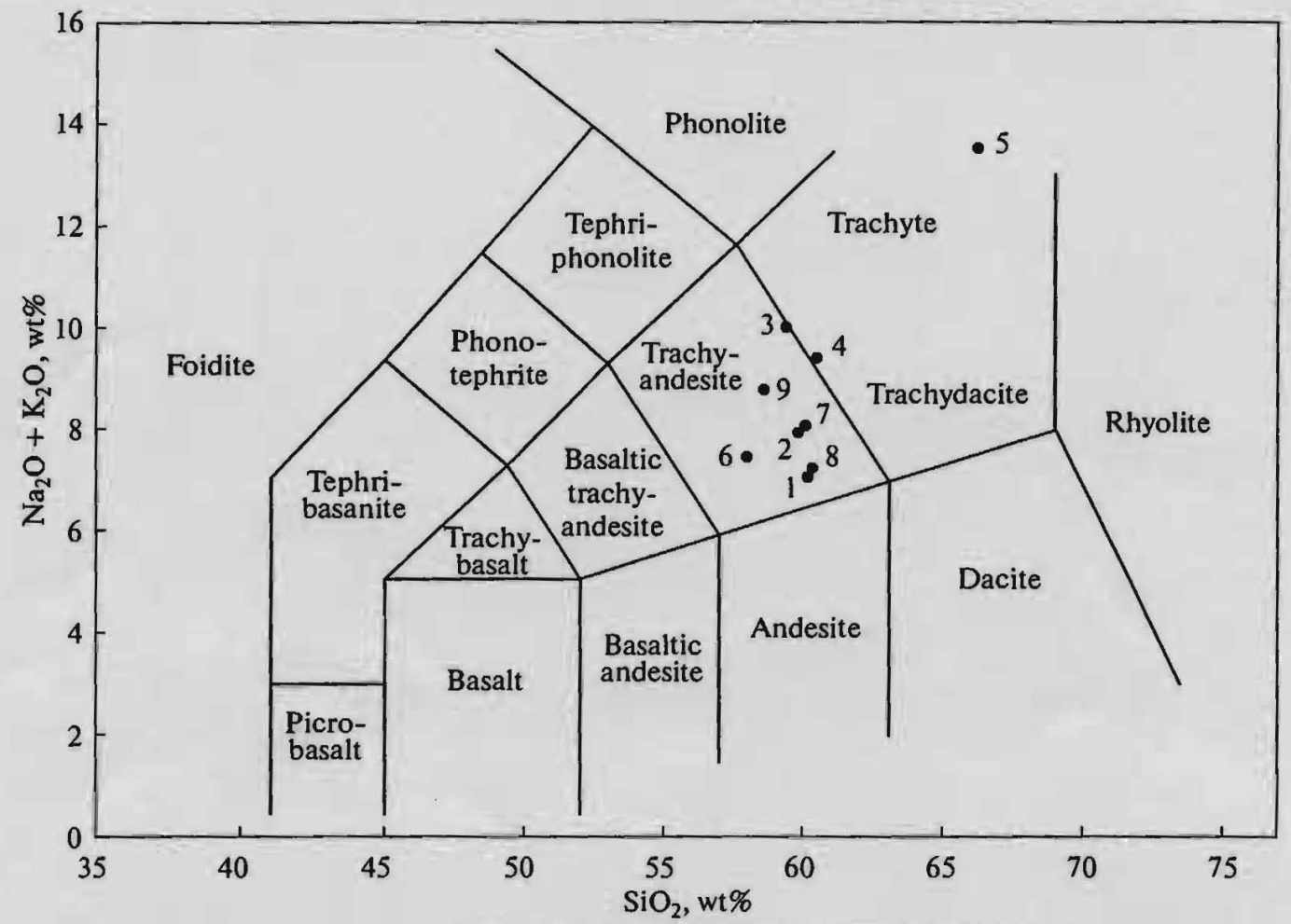

Fig. 4. Chemical compositions of volcanic rocks from the Buchim-Damjan-Borov Dol ore district plotted in the TAS classification diagram (Le Bas, 1986). 1, 2, latite, South Pamuklic; 3, trachyte, South Pamuklic; 4, trachyte, Damjan; 5, alkali trachyte, Crkvisty; 6, latite, Borov Dol; 7, 8, latite Damjan; 9, latite, Borov Dol.

Trace element contents (Table 2) indicate magma fractionation in the course of its evolution. The spidergram (Fig. 5) demonstrates distinct positive Th and U anomalies and slight negative $\mathrm{Nb}$ and $\mathrm{Ti}$ anomalies characteristic of the subduction-related igneous rocks. Thus, the geochemical signatures suggest that the igneous rocks at the deposits under consideration were most likely formed at the mantle-crust interface.

\section{GEOLOGY OF DEPOSITS}

The Buchim deposit is typical of the Lece-Chalkidiki metallogenic zone and related to three isometric, fingerlike stocks of andesitic-trachyandesitic (quartz latitic) porphyry that cuts through the Precambrian biotite, muscovite-biotite, amphibole-biotite gneisses and amphibolites (Fig. 6). Gneisses are the most favorable rocks for ore deposition (Fig. 7).

According to the results of exploration, the copper mineralization covers an area of $1.5-2.0 \mathrm{~km}^{2}$ and is traced to a depth of $300 \mathrm{~m}$. The Central, Bunardzik, VTsnik, and Cukar orebodies are contoured (Fig. 6, I-IV); the Central orebody is the largest in copper reserves. Three orebodies are morphologically related to stocks, and the fourth body is presumably a fragment of a previously existing sheetlike layer of manto-type oxidized and redeposited ore (Fig. 6).
The Central orebody, close to a vertical hollow cylinder in morphology, encircles a small vertical andesitic stock and is largely hosted in country gneiss (Fig. 8). The orebody, including the barren latitic stock, is $500 \mathrm{~m}$ in diameter; the vertical range of ore mineralization is more than $250 \mathrm{~m}$ (Fig. 7).

The Vrsnik orebody is localized in the contact zone of the elongated porphyry stock; its nearly vertical boundaries are conformable to the intrusive contact. The Bunardzik orebody, similar in shape and geological setting but much smaller in size, attends the third stock at its western flank. The Cukar orebody is composed largely of secondary chalcocite ore. It is sheetlike and hosted in gneiss at a certain distance from stocks. $\mathrm{Cu}$ as the main component is accompanied by $\mathrm{Mo}, \mathrm{Au}$, and $\mathrm{Ag}$, which are recovered as by-products. The average grades are $0.3 \% \mathrm{Cu}, 0.01 \% \mathrm{Mo}, 0.35 \mathrm{~g} / \mathrm{t}$ $\mathrm{Au}$, and $1 \mathrm{~g} / \mathrm{t} \mathrm{Ag}$. The oxidation zone was less than than $60 \mathrm{~m}$ thick. The oxidized ore was mined out first.

The country rocks adjoining porphyry stocks are silicified, chloritized, sericitized, and underwent argillic alterartion. The same alterations affected the stocks themselves but with lesser intensity; early potassic alteration developed as well.

Titanite, rutile, magnetite, hematite, chalcopyrite, pyrite, bornite, gold, molybdenite, petzite, calaverite, and argentite were identified as ore minerals. Enargite, 
Table 2. Microelements in volcanic rocks of the Buchim-Damjan-Borov Dol ore district, ppm

\begin{tabular}{|c|c|c|c|c|c|c|c|c|}
\hline Element & 1 & 2 & 3 & 4 & 5 & 6 & 7 & 8 \\
\hline $\mathrm{Cr}^{*}$ & 65 & 38 & 29 & 29 & 64 & 26 & 60 & 50 \\
\hline $\mathrm{Li}^{*}$ & 18 & 9 & 12 & 4 & 4 & 3 & 9 & 9 \\
\hline $\mathrm{Rb}^{*}$ & 54 & 46 & 57 & 61 & 271 & 46 & 3 & 42 \\
\hline $\mathrm{Nb}$ & 10 & 11 & 10 & 8 & 16 & 12 & 9 & 10 \\
\hline Y & 26 & 26 & 23 & 25 & 33 & 28 & 26 & 27 \\
\hline $\mathrm{Sr}$ & 1227 & 1501 & 1349 & 1491 & 926 & 1702 & 1327 & 1633 \\
\hline $\mathrm{U}$ & 5 & 3 & 4 & $<2$ & 9 & 6 & 6 & $<2$ \\
\hline Th & 21 & 30 & 25 & 31 & 37 & 37 & 27 & 23 \\
\hline $\mathrm{Pb}$ & 51 & 67 & 60 & 65 & 72 & 43 & 26 & 71 \\
\hline $\mathrm{Ga}$ & 19 & 19 & 18 & 19 & 20 & 18 & 17 & 19 \\
\hline $\mathrm{Zn}$ & 170 & 69 & 75 & 67 & 33 & 49 & 66 & 60 \\
\hline $\mathrm{Cu}$ & 43 & 51 & 70 & 323 & 8 & 32 & 11 & 52 \\
\hline $\mathrm{Ni}$ & 9 & 7 & 8 & 6 & 6 & 9 & 6 & 6 \\
\hline Co & 16 & 13 & 14 & 13 & 5 & 16 & 6 & 11 \\
\hline $\mathrm{Nd}$ & 46 & 59 & 50 & 48 & - & 59 & 50 & 52 \\
\hline $\mathrm{La}$ & 65 & 76 & 88 & 69 & 61 & 84 & 74 & 98 \\
\hline S & 51 & - & - & 96 & 27 & - & 90 & 28 \\
\hline Hf & 9 & 7 & 11 & 13 & 10 & 11 & 14 & 9 \\
\hline Sc & 11 & 14 & 11 & 10 & $<2$ & 12 & 16 & 14 \\
\hline As & 8 & 4 & 6 & $<3$ & 14 & $<3$ & 8 & 3 \\
\hline
\end{tabular}

Notes: *AAS (Sofia); other analyses—XRF (Switzerland); (1-8) sample numbers.

tetrahydrite, galena, and sphalerite are less abundant. Chalcocite and covellite are predominant in the Cukar orebody, being accompanied by pyrite, tenorite, and occasional native copper, malachite, and azurite.

The ore mineralization was formed in the following sequence. Titanite, rutile, and magnetite crystallized first, followed by pyrrhotite, cubanite, valeriite, and the early generation of chalcopyrite. After deposition of these minerals, the hydrothermal ore-forming solution became enriched in sulfur giving rise to pyrite crystallization. The late chalcopyrite and galena formed at the final stage of ore deposition (Serafimovski, 1993).

At the Borov Dol deposit, porphyry copper mineralization occurs as a ring around the subvolcanic andesitic body that cuts through older volcanic rocks (Fig. 9). The intensely altered volcanic rocks host the ore. Potassic and quartz-sericite alteration are noted at the surface. Down the dip, the orebody morphology is conformable to the andesitic stock. The ore mineralization is stringer-disseminated; ore disseminations (70\%) pre- 


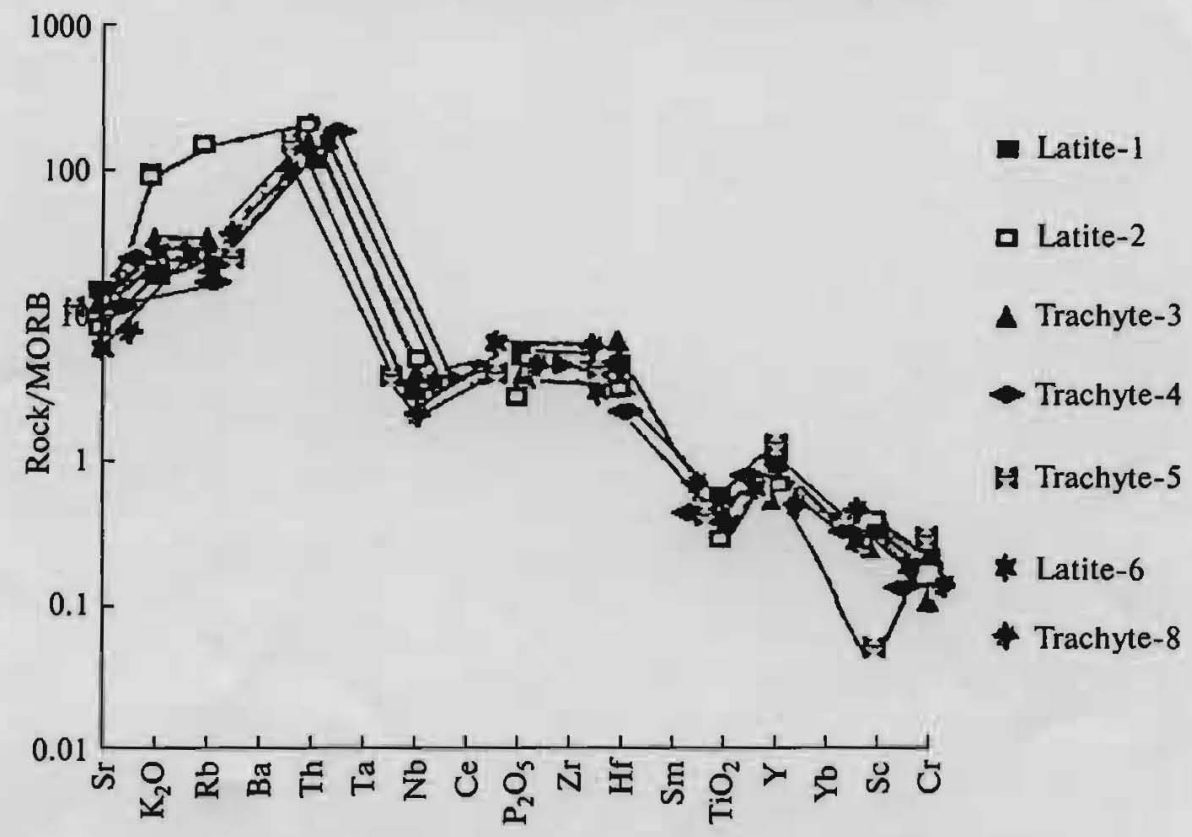

Fig. 5. MORB-normalized trace element contents in volcanic rocks of the Buchim-Damjan-Borov Dol ore district. (1-3) Latite corresponding to nos. $1,2,6$ in Table $3 ;(4-7)$ trachyte corresponding to nos. 4, 5, 6, 8 in Table 3.

vail over ore veinlets $(30 \%)$ (Tudzarov and Serafi- bornite and sporadic enargite, famatinite, galena, and movskii, 1995). tennantite. In general, the ore consists of $\mathrm{Fe}-\mathrm{Ti}$ oxides,

Chalcopyrite as the major mineral in primary ore is accompanied by pyrite, molybdenite, magnetite, gold, $\mathrm{Fe}$ oxides, and $\mathrm{Cu}, \mathrm{Mo}, \mathrm{Zn}, \mathrm{Pb}, \mathrm{Bi}$, and $\mathrm{Ni}$ sulfides. Microscopic examination resulted in identifying pyrite,

Table 3. Microprobe analyses of ore minerals from the Borov Dol and Buchim deposits, wt \%

\begin{tabular}{c|c|c|c|c|c|c}
\hline No. & $\mathrm{Au}$ & $\mathrm{Cu}$ & $\mathrm{Fe}$ & $\mathrm{Co}$ & $\mathrm{Ni}$ & $\mathrm{S}$ \\
\hline 1 & 83.79 & 1.01 & 0.73 & - & - & - \\
2 & - & 34.97 & 30.36 & - & - & 34.68 \\
3 & - & 34.73 & 30.53 & - & - & 34.74 \\
4 & - & 35.17 & 31.14 & - & - & 33.69 \\
5 & - & 0.95 & 2.08 & 4.18 & 51.31 & 41.49 \\
6 & - & 1.25 & 2.04 & 4.39 & 50.87 & 41.45 \\
7 & - & 1.12 & 2.06 & 4.25 & 50.93 & 41.67 \\
8 & - & 1.33 & 2.20 & 4.26 & 50.76 & 41.43 \\
9 & - & - & 24.62 & - & 23.51 & 51.87 \\
10 & - & - & 25.69 & - & 22.99 & 51.32 \\
11 & - & 67.13 & 6.31 & - & - & 26.55 \\
12 & 92.06 & 1.57 & 0.62 & & & \\
13 & 86.0 & 0.46 & - & & & \\
14 & 80.3 & 0.35 & 0.87 & & & \\
15 & 72.53 & 1.26 & 0.68 & & & \\
\hline
\end{tabular}

Notes: Borov Dol deposit: (1) native gold, $(2-4)$ chalcopyrite, $(5-8)$ polydymite, $(9,10)$ bravoite, (11) bornite; the Buchim deposit: (1215) native gold. 


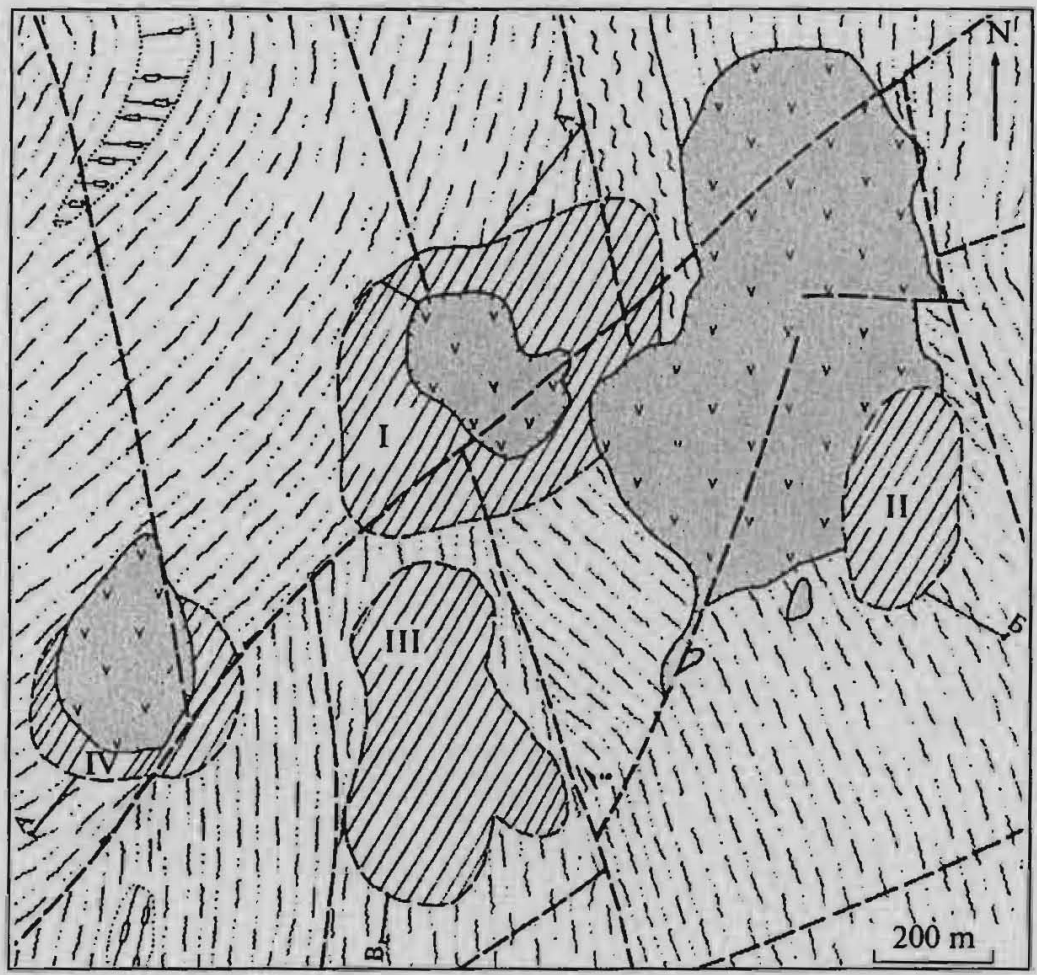

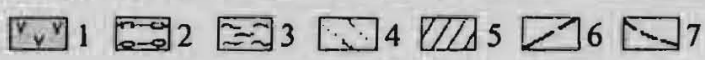

Fig. 6. Geological map of the Buchim deposit. (1) Andesite and latite, (2) amphibolite, (3) muscovite schist, (4) gneiss, (5) orebody, $(6)$ fault, (7) orebody contour. I-IV are orebodies, see text.

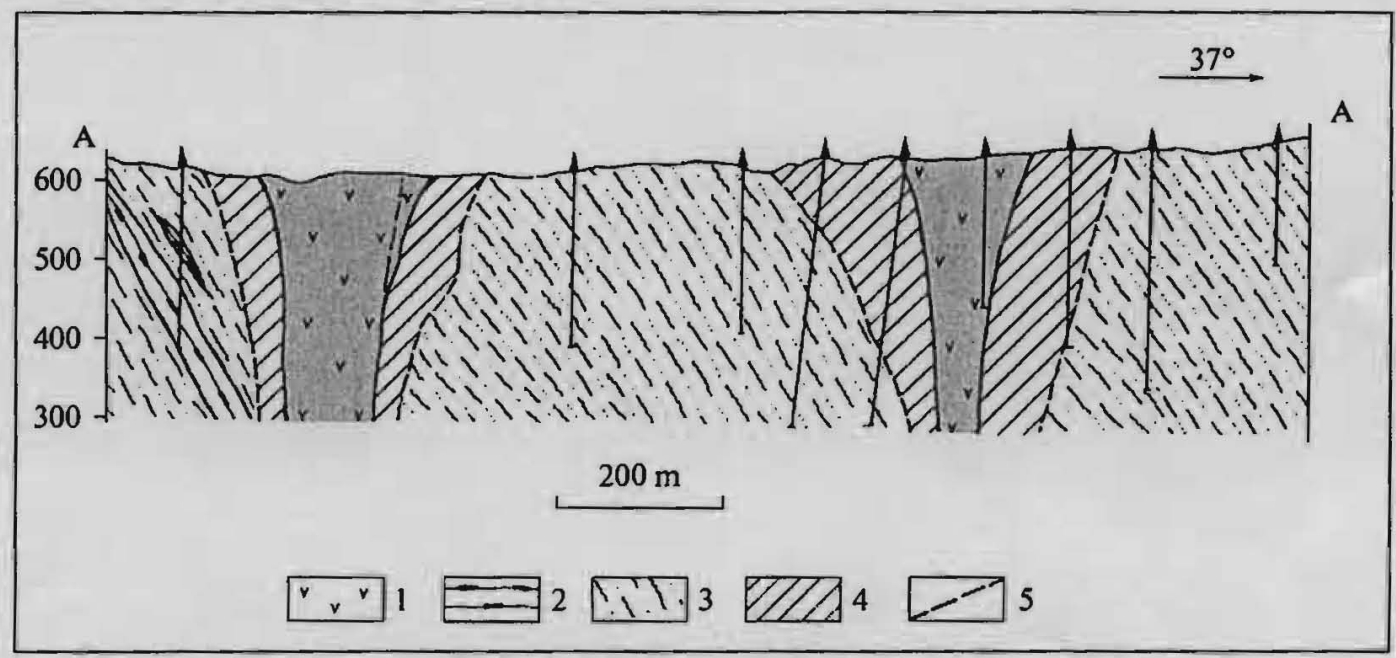

Fig. 7. Geological section across the Buchim deposit. (1) Andesite and latite, (2) amphibolite, (3) gneiss, (4) orebody, (5) fault. See Fig. 6 for section line.

chalcopyrite hematite, magnetite, covellite, chalcocite, pyrrhotite, calcite, sphalerite, galena, native gold, bornite, tetradymite, tennatite, bravoite, and polydymite (Fig. 10). The identification of some minerals was confirmed by microprobe analysis (Table 3 ). Polydymite was identified for the first time; the chemical composition and fineness of native gold was established (Table 3).

Native gold and Au tellurides occur at the Borov Dol deposit. The native gold is associated with all generations of pyrite and noted as inclusions in chalcopy- 


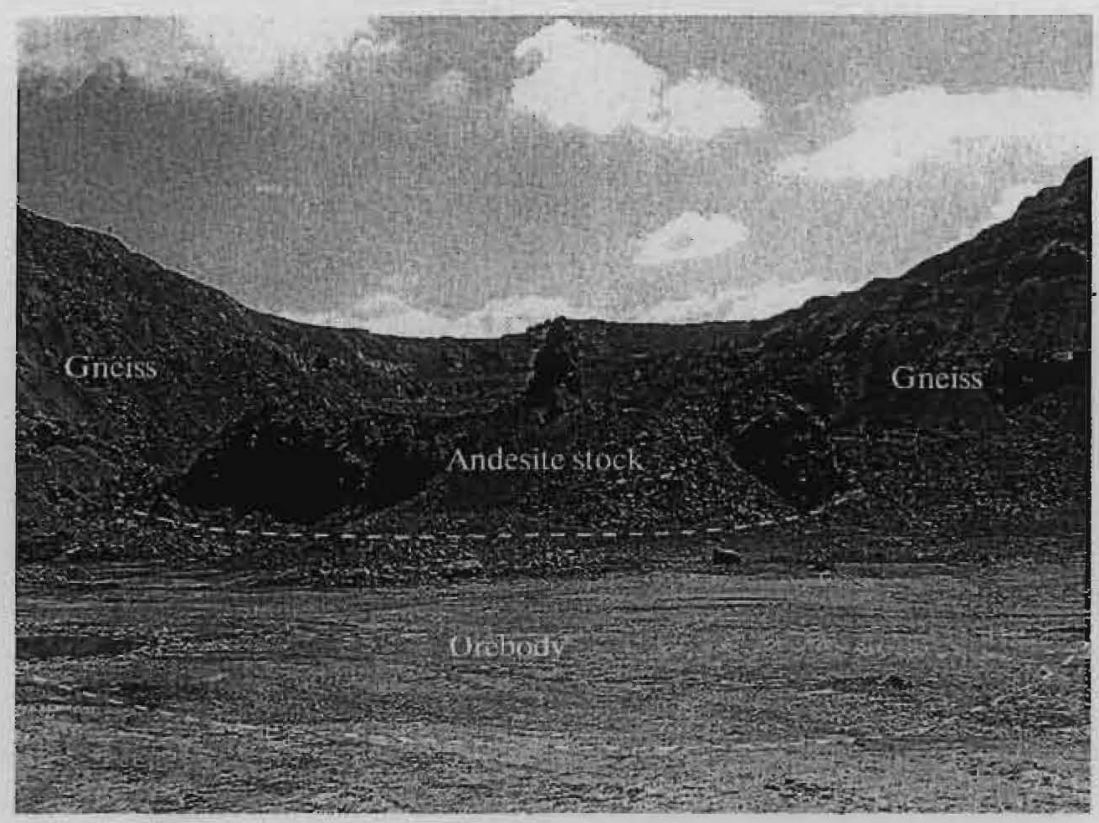

Fig. 8. Open pit of the Central orebody at the Buchim deposit.

rite of the first generation (Fig. 10a) and sphalerite (Stefanova and Serafimovski, 2006). The fineness of gold inclusions up to $7 \mu \mathrm{m}$ in size is as high as 837 (Table 3).

Hematite and magnetite are often associated with pyrite and chalcopyrite; rutile, titanite, ilmenite, and anatase were identified among oxides. Pyrrhotite is the earliest sulfide. Galena and sphalerite are not abundant. Tetrahedrite, tennantite, enargite, bornite, and polydymite are rare ore minerals.

\section{EXOGENIC GOLD}

Exogenic gold was studied during fieldwork and in the laboratory. The fieldwork consisted of panning of creeks that drain the Borov Dol deposit. Pyrite, magnetite, chalcopyrite, ilmenite, amphibole, pyroxene, zircon, and garnet are the most frequent minerals in heavy concentrates. Thirty-five gold grains were detected and studied. Oblong, equant, and oval gold grains (Fig. 11) varied from $150 \mu \mathrm{m}$ to $1 \mathrm{~mm}$ in size. The morphology of grains shows that they were derived from a primary source (Zakharova, 1994; Petrovskaya, 1973). Zonal and porous internal structure is characteristic (Fig. 11).

The microprobe results (Table 4) show that native gold is of high fineness (834-981). The $\mathrm{Ag}$ content varies from 0.82 to $15.85 \mathrm{wt} \%$. The central parts of some grains are depleted in $\mathrm{Ag}$ relative to their margins. In general, gold grains are uniform in composition except for grain BD-9 distinguished by extremely high fineness (977-984) and low Ag content (0.82$1.09 \%)$. The $\mathrm{Ag}$ content in particular samples ranges from 7.62 to $48.91 \%$. The $\mathrm{Cu}$ impurity in gold is uniform $(0.4-0.6 \%)$. Native gold grains contain $0.02-$ $0.05 \% \mathrm{Fe}$. The average Au content in gold grains from the Borov Dol deposit is $91.2 \%(88.44-98.15 \%)$; the average $\mathrm{Ag}, \mathrm{Cu}$, and $\mathrm{Fe}$ contents are $7.87,0.49$, and $0.036 \%$, respectively. Comparison with the data from Table 3 shows that exogenic and endogenic gold from the Borov Dol and Buchim deposits is quite identical in fineness and $\mathrm{Cu}$ and $\mathrm{Fe}$ impurities. At the same time, endogenic and exogenic gold grains differ appreciably in size.

The results show that the composition of exogenic gold and its morphology may be used as direct prospecting guides of Au-bearing porphyry copper mineralization. Panning and the subsequent study of morphology and chemical composition of native gold particles is an efficient technique for prospecting $\mathrm{Au}$ bearing porphyry copper deposits.

\section{DISCUSSION}

As was supposed at the early stages of geological studies, the parental magma of the volcanic-intrusive complex in the Serbo-Macedonian metallogenic province was a product of partial melting of the continental crust and related to the collision of continental blocks at a depth. The magma ascended to a shallow level along deep faults.

Later on, based on the ${ }^{87} \mathrm{Sr} /{ }^{86} \mathrm{Sr}$ isotope ratios (0.706633-0.706928) and trace-element geochemistry, Serafimovski et al. (1996) showed that volcanic rocks of the studied district were formed as products of mixing of crustal and mantle-derived materials. It was 


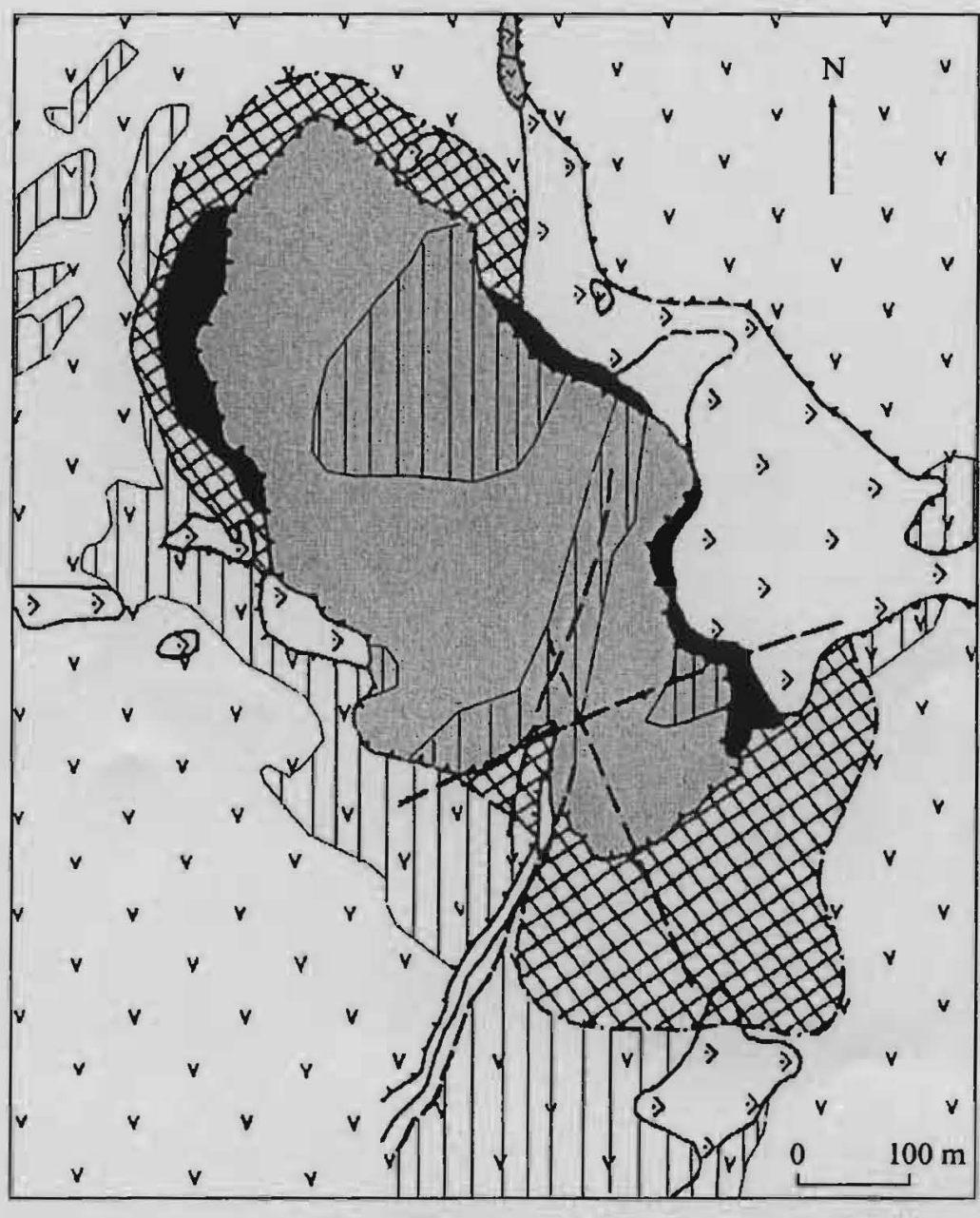

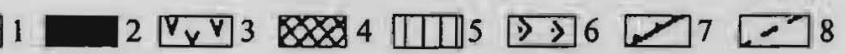

Fig. 9. Geological section of the Borov Dol deposit. (1) Andesite, (2) breccia, (3) quartz latite, (4) copper mineralization, (5) hydrothermally altered rocks, (6) volcanic and sedimentary rocks, (7) contour of intrusive body, (8) fault.

also noted that trace element distribution in volcanic rocks of the Buchim-Damjan-Borov Dol district is similar to that in igneous rocks of active continental margins (Boev et al., 1992).

The geochemical data presented in this paper (Fig. 5) allow us to suggest that the igneous rocks of this ore district were formed as a result of subduction at the crust-mantle interface.

The formation of the porphyry system in the Buchim-Damjan-Borov Dol ore district was caused by injection of moderately fractionated melt enriched in volatile components from a deep-seated magma chamber (Miller and Groves, 2000). The intrusive stocks in such systems commonly make up clusters consisting of separate fingerlike intrusions varying in composition from diorite via monzodiorite to monzo- nite, and the latter are accompanied by stockwork mineralization.

Thus, the monzonite stocks in the Buchim-Damjan-Borov Dol ore district formed at the final stage of fractionation of the parental shoshonitic melt (Fig. 3).

The study of stable isotopes is necessary to specify the origin of ore minerals. The $\delta 34 \mathrm{~S}$ in pyrite from the Buchim deposit varies from +0.16 to $+2.53 \%$ o $(+1.06 \%$, on average) (Serafimovski et al., 1996). The deposits with such sulfur isotopic composition are related to felsic igneous rocks. The sulfur from the Borov Dol deposit is characterized by enrichment in the light isotope $\left(\delta^{34} \mathrm{~S}\right.$ is $0-7 \%$ ) as is characteristic of a crustal source (Tudzarov and Serafimovski, 1995). The difference in sulfur isotopic composition in closely spaced deposits may be explained by their specific geological settings. As was mentioned above, the 

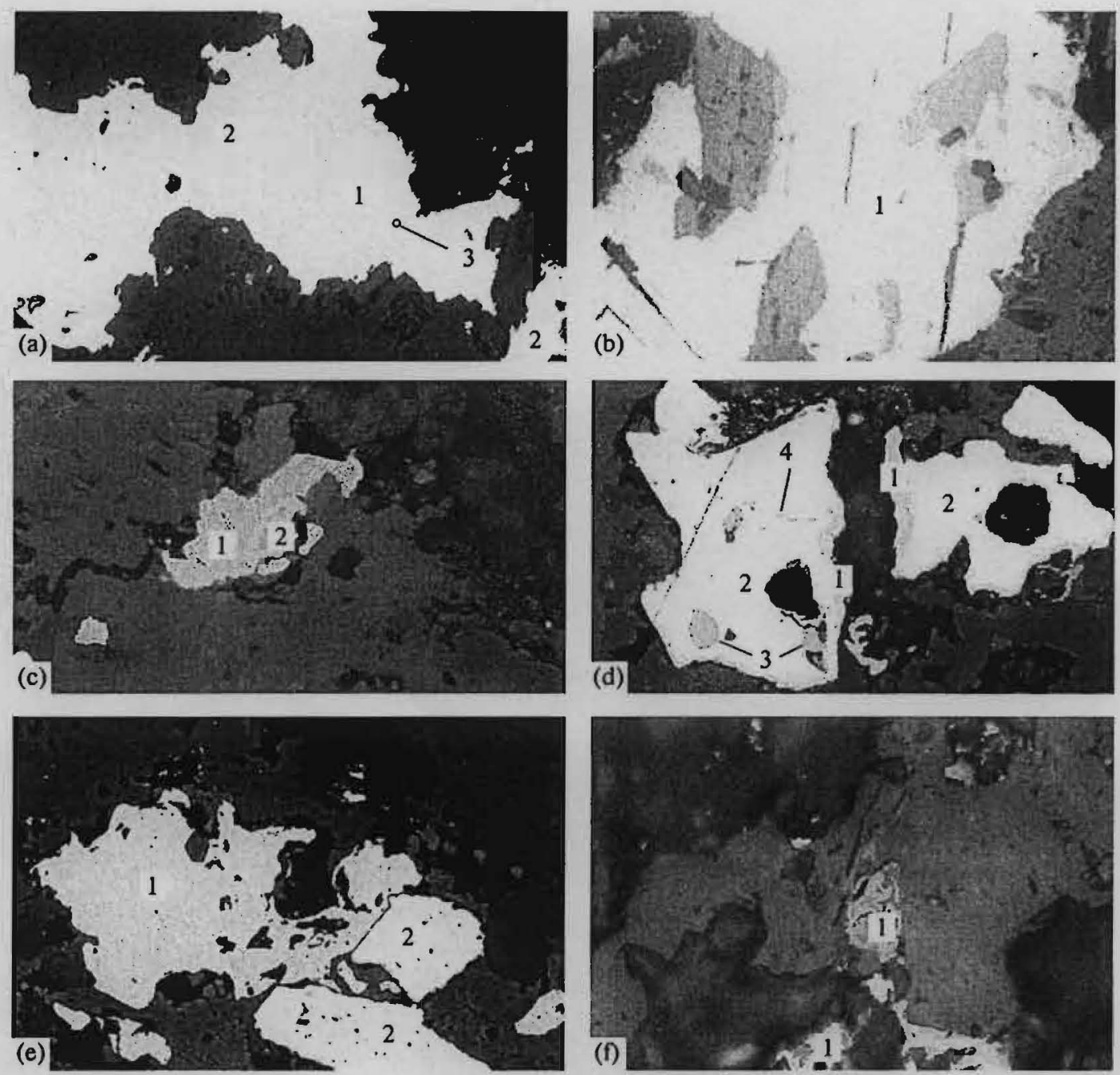

Fig. 10. Ore minerals from the Borov Dol deposit: (a) large allotriomorphic chalcopyrite grain (2) with polydymite inclusion (1) and finely dispersed gold (3), polished section, magn. 126; (b) allotriomorphic magnetite grains (1), magn. 126; (c) chalcopyrite (I) corrodes bornite (2), magn. 126; (d) subhedral pyrite grain (2) with chalcopyrite (3), sphalerite (4), and bravoite inclusions, magn. 126; (e) allotriomorphic and subhedral chalcopyrite (1) and pyrite (2) grains, magn. 63; (f) allotriomorphic covellite grains, magn. 126.

Buchim deposit is located in the SMM, whereas the Borov Dol deposit, in the VZ (Fig. 12). It cannot be ruled out that sulfur was partly derived from host sedimentary rocks. At the same time, the sulfur isotopic composition of sulfides from the studied deposits almost completely fits the $\delta^{34} \mathrm{~S}$ range $(-5$ to $+1 \%$ ) typical of the known porphyry copper deposits (Rollinson, 1993).

The carbon isotopic compositions $\left(\delta^{13} \mathrm{C}\right)$ and oxygen isotopic composition $\left(\delta^{18} \mathrm{O}\right)$ of calcite from the ore mineral assemblage show that ore-forming solutions consisted largely of meteoric water with $\mathrm{pH}>7$ (Serafimovski et al., 1996). As follows from the fluid inclusion study, these solutions belongs to the sodium chloride type and their salinity varied from 10 to $25 \mathrm{wt} \%$ $\mathrm{NaCl}$ equiv. The ore components were transferred by those solutions in the form of complex ions containing $\mathrm{Na}$ and $\mathrm{K}$ chlorides and less frequently as sulfates and carbonates. The ore formation proceeded in the temperature interval $490-200^{\circ} \mathrm{C}$ (Serafimovski et al., 1996).

It can be suggested that the primary magmatic chamber was a source of copper; however, subvolcanic intrusive stocks at the considered deposits are too small to mobilize that amount of copper, which is currently contained in orebodies. Hence, a deep-seated magmatic source of copper should be a rather large intrusive body (Fig. 12). It cannot be ruled out that a large body of ore-bearing magma that formed at a cer- 


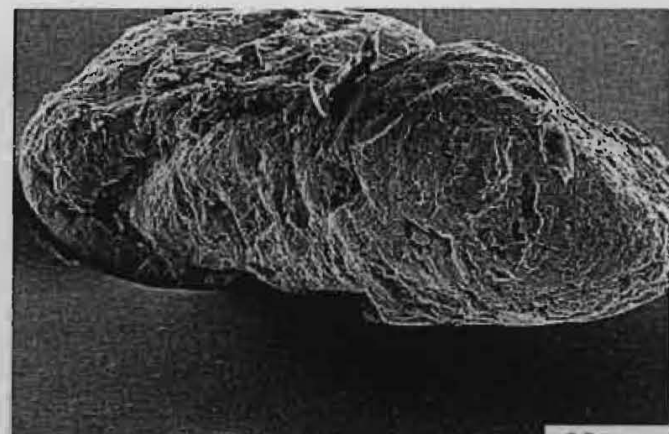

(a)

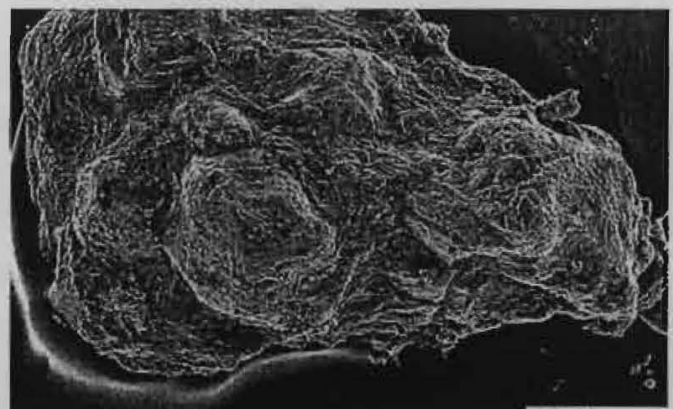

(c)

$100 \mu \mathrm{m}$
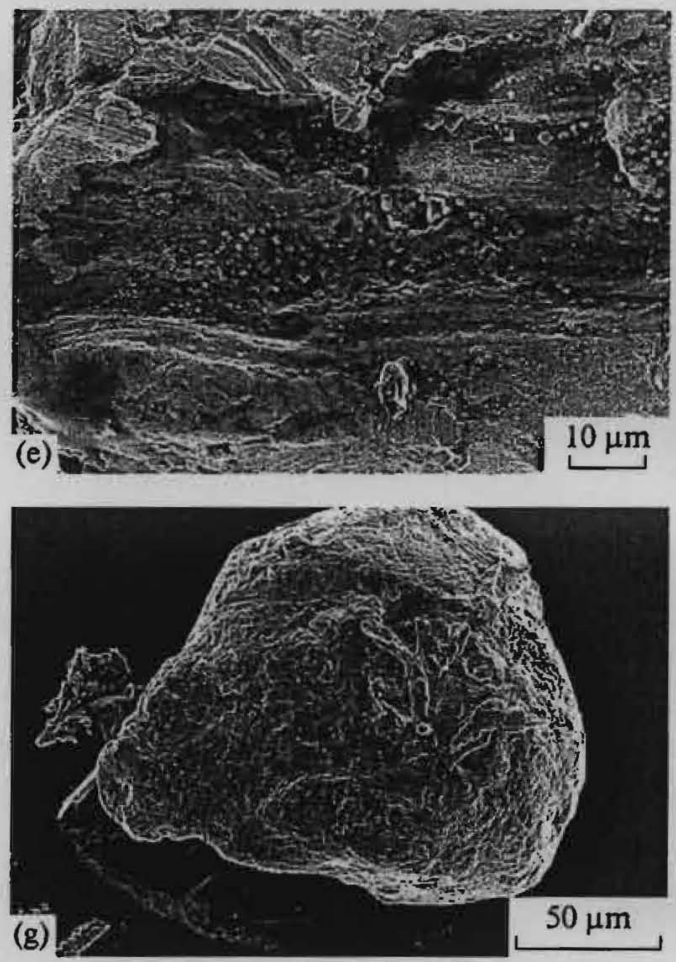

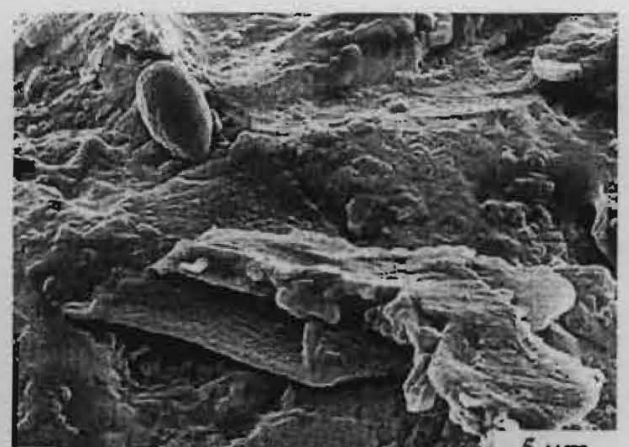

(b)

$5 \mu \mathrm{m}$
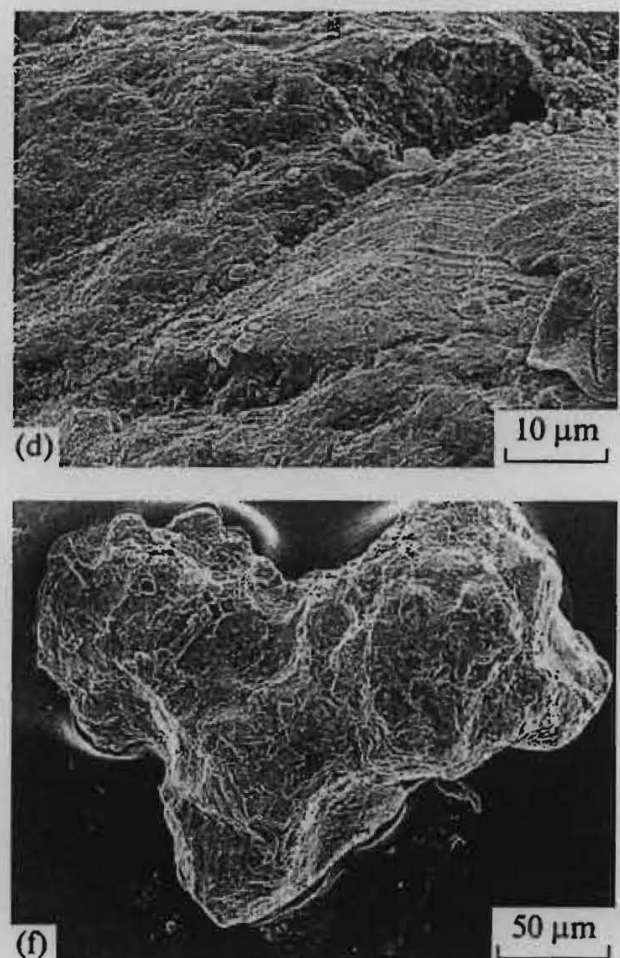

(f)

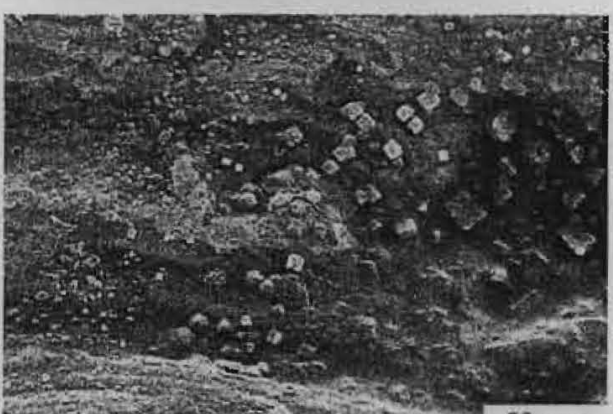

(h) $-40 \mathrm{~m}$

Fig. 11. Native gold grains and their aggregates from the Borov Dol deposit: (a) oblong rodlike aggregate; (b) gold sheets, closeup of panel (a); (c) equant gold aggregate; (d) close-up of panel (c); (e, f) gold crystals, close-ups of panel (d); (g) ball-shaped gold aggregate; $(h)$ irregular equant aggregate. 
Table 4. Microprobe analyses of native gold from the Borov Dol deposit, wt \%

\begin{tabular}{|c|c|c|c|c|c|c|}
\hline Sample & $\begin{array}{l}\text { Crater } \\
\text { in grain }\end{array}$ & $\mathrm{Au}$ & $\mathrm{Ag}$ & $\mathrm{Cu}$ & $\mathrm{Fe}$ & $\Sigma$ \\
\hline \multirow[t]{4}{*}{$\mathrm{BD}-5$} & 1 - center & 95.50 & 4.26 & 0.53 & 0.08 & 100.4 \\
\hline & $2-$ margin & 94.31 & 4.4 & 0.42 & 0.08 & 99.21 \\
\hline & $3-\gg$ & 95.40 & 3.56 & 0.46 & - & 99.42 \\
\hline & Average & 95.07 & 4.07 & 0.47 & 0.05 & \\
\hline \multirow[t]{4}{*}{ BD-5 } & $1-$ margin & 90.96 & 8.92 & 0.55 & - & 100.4 \\
\hline & $2-\gg$ & 87.31 & 12.66 & 0.39 & - & 100.3 \\
\hline & $3-\gg$ & 83.45 & 15.77 & 0.34 & 0.26 & 99.82 \\
\hline & Average & 87.24 & 12.45 & 0.42 & 0.08 & \\
\hline \multirow[t]{3}{*}{ BD-9 } & 1 - center & 90.87 & 8.51 & 0.61 & - & 99.98 \\
\hline & 2 - margin & 86.02 & 12.60 & 0.60 & - & 99.22 \\
\hline & Average & 88.44 & 10.55 & 0.65 & 0 & \\
\hline \multirow[t]{10}{*}{ BD-10,Grain I } & 1 - center & 94.85 & 4.57 & 0.36 & 0.13 & 99.91 \\
\hline & $2-$ margin & 93.09 & 5.95 & 0.38 & - & 99.40 \\
\hline & $3-\gg$ & 91.27 & 7.98 & 0.61 & 0.15 & 99.35 \\
\hline & $4-\gg$ & 95.10 & 3.77 & 0.24 & - & 99.10 \\
\hline & $5-\gg$ & 95.69 & 3.57 & 0.39 & - & 99.65 \\
\hline & $6-\gg$ & 93.70 & 5.71 & 0.35 & - & 99.75 \\
\hline & $7-\gg$ & 96.04 & 2.94 & 0.59 & - & 99.57 \\
\hline & $8-\gg$ & 93.24 & 5.67 & 0.47 & 0.15 & 99.52 \\
\hline & $9-\gg$ & 92.30 & 6.81 & 0.54 & - & 99.65 \\
\hline & Average & 93.92 & 5.21 & 0.43 & 0.04 & \\
\hline \multirow[t]{9}{*}{ BD-10, Grain 2} & 1 - center & 93.54 & 5.62 & 0.39 & 0.09 & 99.63 \\
\hline & $2-$ margin & 89.31 & 9.82 & 0.59 & - & 99.72 \\
\hline & $3 \rightarrow$ & 88.39 & 10.05 & 1.56 & - & 99.58 \\
\hline & $4-\gg$ & 87.71 & 11.65 & 0.31 & 0.09 & 99.75 \\
\hline & $5-\gg$ & 90.71 & 8.81 & 0.47 & - & 99.98 \\
\hline & $6-\gg$ & 93.13 & 6.05 & 0.50 & - & 99.67 \\
\hline & $7-\gg$ & 90.65 & 8.97 & 0.29 & 0.08 & 99.98 \\
\hline & $8-\gg$ & 92.26 & 6.54 & 0.53 & - & 99.32 \\
\hline & Average & 90.71 & 8.43 & 0.58 & 0.03 & \\
\hline \multirow[t]{5}{*}{ BD-10, Grain 3} & 1 - center & 93.37 & 5.94 & 0.34 & 0.18 & 99.82 \\
\hline & $2-$ margin & 89.39 & 9.61 & 0.61 & 0.21 & 99.81 \\
\hline & $3-\gg$ & 92.27 & 7.04 & 0.65 & 0.14 & 100.1 \\
\hline & $4-\gg$ & 92.40 & 6.98 & 0.42 & 0.15 & 99.95 \\
\hline & Average & 91.85 & 7.39 & 0.50 & 0.17 & \\
\hline
\end{tabular}

tain depth could have provided a sufficiently large porphyry copper deposit; however, such deposits are so far unknown not only in the considered ore district but also in the Lece-Chalkidiki metallogenic zone as a whole.

Part of the copper could have been mobilized from ultramafic rocks, which occur in both the SMM as amphibolites and in the VZ as peridotite and serpen- tinite intruded by Cenozoic porphyry intrusions. Taking into account that the Neogene calc-alkaline igneous complex in the Serbo-Macedonian province is depleted in copper in comparison with the Cretaceous igneous rocks in the Bor ore district (Karamata and Lovric, 1978), such a possibility seems more realistic. The inferred remobilization of copper from serpentinites and ultramafic rocks of the VZ or from Cyprustype masiive sulfide deposits abundant in the Balkan 


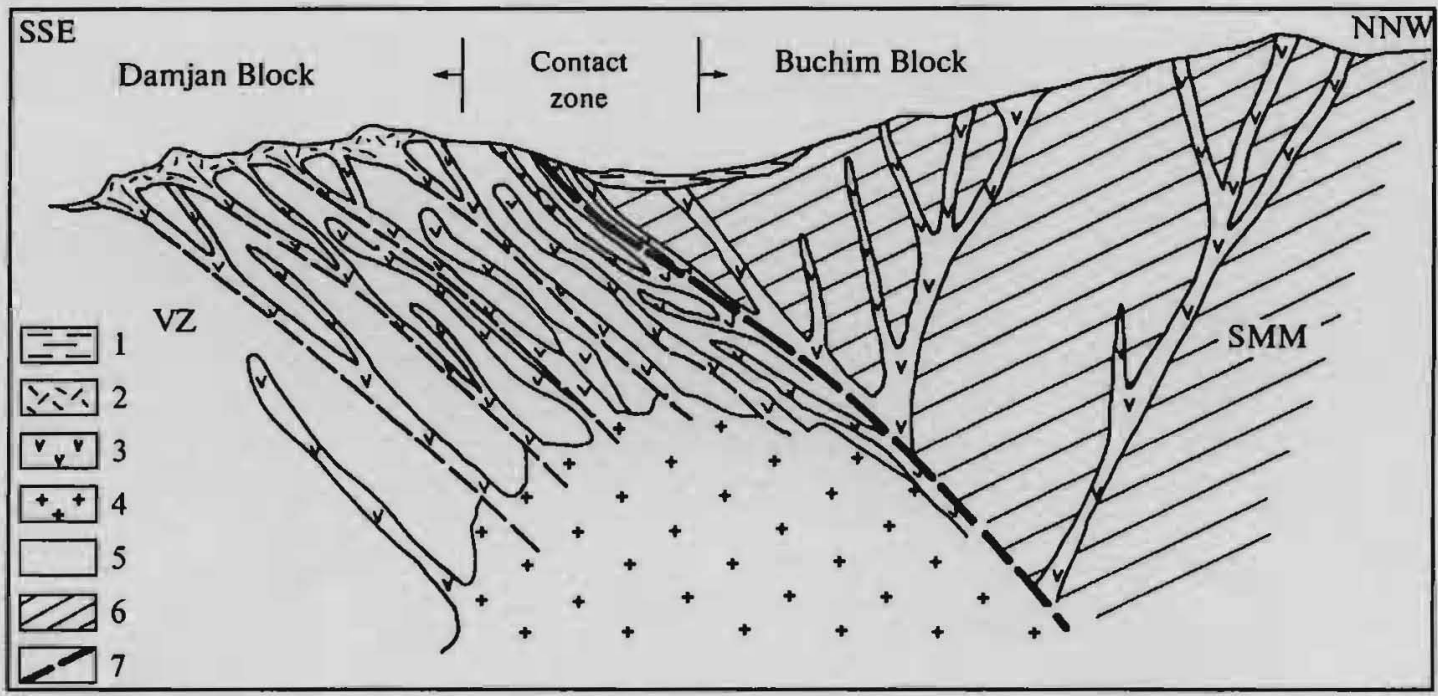

Fig. 12. A model of magmatic system in the Buchim-Damjan-Borov Dol ore district. (1) Pliocene-Quaternary rocks; (2) volcanic rocks; (3) subvolcanic bodies; (4) granitoids; (5) ultramafic rocks, granitoids, Cretaceous and Paleogene rocks in rocks in the Vardar Zone (VZ); (6) gneiss, muscovite schist, and amphibolite in the Serbo-Macedonian Massif (SMM); (7) faults.

region is consistent with the small size of the porphyry copper deposits and low metal contents therein, as is typical of regenerated deposits (Schneiderhön, 1957). Probably, this is precisely the main difference in the formation conditions between dwarf and giant deposits.

In conclusion, it should be noted that no economic copper mineralization was found in magnetite-hematite skarn of the Damjan ore field (Fig. 2) in the Buchim-Borov Dol ore district, although this skarn formed at the contact of carbonate flysch with subvolcanic andesite identical in composition and age to the porphyry stocks at the Buchim and Borov Dol deposits (Fig. 12). It is quite probable that copper mineralization in the Damjan ore field has eroded. Such a possibility is supported by the data on base-metal skarn deposits in Karamazar (Zharikov, 1959, 1968), which demonstrate distinct zoning with base-metal mineralization at the upper levels and hematite-magnetite mineralization at the lower levels. This interpretation is consonant with conclusions made by Cifliganec (1993) on the basis of metasomatic zoning, which indicates that the Damjan ore field has been eroded to the greatest depth, the Buchim deposit eroded not so deeply, and the Borov Dol deposit has hardly been eroded at all.

\section{ACKNOWLEDGMENTS}

This study was supported by the Russian Foundation for Basic Research, project nos. 08-05-00135 and 09-05-00423.

\section{REFERENCES}

1. M. Le Bas, "Chemical Classification of Volcanic Rocks Based on the Total Alkali-Silica Diagram," J. Petrol. 27 (3), 745-750 (1986).

2. P. Blevin, "The Petrographic and Compositional Character of Variably K-Enriched Magmatic Suites Associated with Ordovician Porphyry $\mathrm{Cu}-\mathrm{Au}$ Mineralisation in the Lachlan Fold Belt, Australia," Mineral. Deposita 37, 87-99 (2002).

3. B. Boev, T. Serafimovski, and S. Lepitkova, "Isotopic $\mathrm{Sr}$ Composition of Tertiary Volcanic Rocks in Macedonia," Geol. Masedonica 5, 31-38 (1992).

4. R. J. Chapman, R. C. Leake, N.R. Moles, et al., "The Applications of Microchemical Analysis of Alluvial Gold Grains to the Understanding of Complex Local and Regional Gold Mineralization: A Case Study in the Irish and Scottish Caledonides," Econ. Geol. 95, 1753-1773 (1994).

5. V. Cifliganec, Copper Mineralization in the Republic of Macedonia: Types and Distribution Pattern (Geol. Dept., Faculty Min. Geol., Goce Del'飞ev Univ., Stip, 1993) Spec. Issue, Vol.1.

6. V. Cifliganec, B. Kogan, and S. Jankovic, "Mode of Occurrence and Distribution Pattern of Gold in the Buchim Porphyry Copper Deposit, Republic of Macedonia," Geol. Macedonica 8 (1), 1-12 (1994).

7. D. R. Cooke, P. Hollings, and J. Walshe, "Giant Porphyry Deposits: Characteristics, Distribution, and Tectonic Controls," Econ. Geol 100 (5), 801-816 (2005).

8. N. Dumurdzanov, T. Serafimovski, and B.C. Burchfiel, "Cenozoic Tectonics of Macedonia and Its Relation to the South Balkan Extensional Regime," Geosphere, No. 1, 1-22 (2005). 
9. S. Jankovic, M. Petkovic, I.N. Tomson, et al., "Porphyry Copper Deposits in the Serbo-Macedonian Province, Southeastern Europe," in European Copper Deposits (Geol. Soc. Amer. Spec. Publ., 1980), No.1, pp. 96-103.

10. S. Karamata and A. Lovric, "The Age of Metamorphic rocks of Brezovica and Its Importance for the Explanation of Ophiolite Emplacement," Bull. Acad. Serbe Sci., No. 17, 1-9 (1978).

11. S. Karamata, R. Stojanov, T.Serafimovski, et al., Tertiary Magmatism in the Dinarides, Vardar Zone and the Serbo-Macedonian Massif," Geol. Macedonica 6 (2), 125-186 (1992).

12. D. Miller and D.I. Groves, Potassic Igneous Rocks and Associated Gold-Copper Mineralization (Springer, Berlin, 2000).

13. A. Pecerrillo and S. R. Taylor, "Geochemistry of Eocene Calc-Alkaline Volcanic Rocks from Kastomonov Area, Northern Turkey," Contrib. Mineral. Petrol. 58, 63-81 (1976).

14. M. Petkovic, Cheochemical Exploration in the DamjanBuchim Ore District and the Adjacent Territory (RGF-Beograd, Beograd, 1968).

15. N. V. Petrovskaya, Native Gold (Nedra, Moscow, 1973) [in Russian].

16. H. Rollinson, Using Geochemical Data: Evaluation, Presentation, Interpretation (Longman, Harlow, 1993).

17. T. Serafimovski, Structural-Metallogenetic Features of the Lece-Chalkidiki Zone: Types of the Mineral Deposits and Distribution (Geol. Dept., Faculty Min. Geol., Goce Del'Eev Univ., Stip, 1993) Spec. Issue.

18. T. Serafimovski and Cifliganec V., "The Buchim Ore District: Geological Setting and Types of Ore Mineralization," in Terranes of Serbia: The Formation of the Geological Framework of Serbia and the Adjacent Regions (Beograd, 1996), pp. 341-347.

19. T. Serafimovski, V. Cifliganes S . Jancovic, et al., "Genetic Model of the Buchim Porphyry Copper Deposit, Republic of Macedonia," in Plate-Tectonic Aspects of the Alpine Metallogeny in the Carpatho-Balkan Region, "in Proceedings of the Annual Meeting (Sofia, 1996), Vol. 1, pp. 63-73.
20. T. Serafimovski, N. Tudzarov, K. Popov, et al., "Types of Geochemical Associations in the Borov Dol-Sopur Area: Interpretation of the Data of Primary and Secondary Halos," Geol. Macedonica 10 (1), 1-15 (1997).

21. H. Schneiderhöhn, "Advances in Perception of Secondary Hydrothermal and Regenerated Deposits," in Regenerated Ore Deposits (Inostr. Liter., Moscow, 1957).

22. V. Stefanova, T. Serafimovski, V. Nedelkov, and V. Kovacev, "Petrologic and Geochemical Characteristics of the Volcanic Rocks in the Buchim District," Geol. Macedonica 20, 1-11 (2006).

23. R. Stojanov and T. Serafimovski, "Main Characteristics of Tertiary Magmatism in the Buchim-Borov Dol District," in Proceedings of XII Geological Congress of Jugoslavia (Ohrid, 1990), pp. 404-424.

24. I. N. Tomson, T. Serafimovskii, and N. T. Kochneva, "Cenozoic Metallogeny of Eastern Macedonia," Geol. Rudn. Mestorozhd. 40 (4), 195-204 (1998) [Geol. Ore Deposits 40 (4), 175-183 (1998)].

25. N. Tudzarov and T. Serafimovski, "Geotectonic Setting and Metallogenetic Features of the Borov Dol Porphyry Copper Deposit," Geol. Macedonica 9 (1), 89-96 (1995).

26. A. V. Volkov, N. E. Savva, A. A. Sidorov, et al., "Spatial Distribution and Formation Conditions of $\mathrm{Cu}-\mathrm{Au}$ Porphyry Deposits in the Northeast of Russia," Geol. Rudn. Mestorozhd. 48 (6), 512-539 (2006) [Geol. Ore Deposits $48(6), 448-472(2006)]$.

27. A. V. Volkov, T. Serafimovskii, N. T. Kochneva, et al., "The Alshar Au-As-Sb-Tl Epithermal Deposit, Southern Macedonia," Geol. Rudn. Mestorozhd. 48 (3), 175-192 (2006) [Geol. Ore Deposits 48 (3), 175-192 (2006)].

28. E. M. Zakharova, Mineralogy of Placers (Nedra, Moscow, 1994) [in Russian].

29. V. A. Zharikov, "Skarn Deposits," in Genesis of Endogenic Ore Deposits (Nedra, Moscow, 1968) [in Russian].

30. V. A. Zharikov, Geology and Metasomatism of the BaseMetal Skar5n Deposits in the Western Karamazar (USSR Acad. Sci., Moscow, 1959) [in Russian]. 